\title{
The Connection between Consciousness and the World in Conceptual Theories of Reflexivity, Functionalism, and Depth Psychology
}

\section{Зв'язок «Свідомості» й «Світу» в концептуальних теоріях рефлексивності, функціоналізму і глибинної психологїі}

\author{
Svitlana Kalishchuk \\ Ph.D. in Psychology, Assistant Professor, Doctoral Student, \\ Department of General, Age and Pedagogical Psychology, Borys \\ Grinchenko Kyiv University, Kiev (Ukraine) \\ ORCID ID: https://orcid.org/0000-0002-1749-7856 \\ Researcher ID: F-4321-2019 \\ E-mail: klana_@ukr.net

\section{Світлана Каліщук} \\ Кандидат психологічних наук, доцент, докторант кафедри \\ загальної, вікової та педагогічної психології, Київський універ- \\ ситет імені Бориса Грінченка, м. Київ (Україна)
}

\section{ABSTRACT}

The article sets out the research aspects of the description of the conceptual psychological level of explanation of personality consciousness: historicalpsychological, procedural-dynamic and personalistic. A sequence of paradigmatic prisms of the study of consciousness is constructed from the methodology of reflexivity to the modern stage and its new canon. A methodological model of a single plane of analysis of numerous psychological theories of consciousness is

Address for correspondence, e-mail: kpnu_lab_ps@ukr.net Copyright: (c) Kalishchuk Svitlana

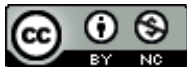

(C) Kalishchuk Svitlana

DOI (article): https://doi.org/10.32626/2227-6246.2019-46.178-198 
proposed. The coordinate axes of the research plane of theories of consciousness are highlighted. The ordinate is represented by the dichotomous axis: "General empirical, meeting with the world - Individual empirical, unique separation of oneself from the world»; the abscissa is represented by the axis "Typical substantial, universal, attributive - Unique substantial, sensual delight from the infinite perfection of the world and trust in it». The features of the interpretation of consciousness from the perspective of three psychological foundations are analyzed: reflexivity, functionalism and deep psychology with isolating the belonging of each approach to one of the four partial spaces for explaining consciousness: "About the World", "In the World", "Me and the World", "with the World». It is determined that the individuality and originality of the ensemble of human interaction with the world on the basis of "reflection in another", sets the potential for generating infinity of "slices» of reality. Therefore, the methodology of reflexivity is placed in the center of the coordinate plane of the study of consciousness due to the fact that this process is potentially capable of activating all possible aspects of the action of consciousness: "consciousness about the World", "consciousness in the World", "consciousness of Me and the World", "consciousness with the World». The quadrant "consciousness in the World", which is created by the axes "Typical substantial - Individual substantial» due to its phenomenological nature, corresponds to the views on the processualism of consciousness of W. James, according to which consciousness is primary, functionally holistic and represents a «stream». The tendency to explain what is characteristically subjective through a construct, which is essentially subjectively unknown, relates the deep direction of consciousness research to the "About the World" plane, to the quadrant that is outlined by the axes "General Empirical - Typical Empirical».

Key words: "consciousness about the World», "consciousness in the World", "consciousness of Me and the World", "consciousness with the World", methodology of reflexivity, functionalism, deep psychology.

\section{Вступ}

Філософські й природничо-наукові онтологічні моделі свідомості виступають невід'ємними фундаментальними засадами психологічного дослідження феномену «свідомість» . Вони визначають обсяг дослідницького поля та його панорамність; уводять категорії опису й аналізу з боку певної наукової грані: філософської, психофізіологічної, квантово- 
механічної, системно-математичної; пояснюють психофізіологічні, квантові та системні механізми здійснення дії свідомості; з'ясовують основні компоненти побудови системної «семантичної території» свідомості особистості тощо (Каліщук, 2019).

Сутність саме психологічних теорій дослідження свідомості полягає у визначенні «мікросвіту» людини, внутрішнього змісту свідомості, включаючи буттєві, рефлексивні, духовні шари свідомості та їх складові й, головне, спосіб взаємодії зі «Світом». Ураховуючи багатоаспектність психологічних досліджень свідомості, представлених в енциклопедичних працях В. Аллахвердова, О. Леонтьєва, В. Налімова, С. Пріста, Р. Фрейджера, А. Фурмана, Г. Ханта (Аллахвердов, 2001; Леонтьев, 1975; Налимов, 1989; Прист, 2000; Фрейджер, 2002; Фурман, 2017; Хант, 2004), у якості дослідницьких аспектів опису концептуального рівня дослідження свідомості особистості можуть бути обрані три головні, a саме: історико-психологічний, який відображає змістовну i логіко-предметну площину; процесуально-динамічний, що віддзеркалює реальний процес отримання й накопичення психологічного знання, детермінований сукупністю чинників та ідей; персоналістичний, який розкриває роль суб'єкта психологічної думки й індивідуальний характер світосприйняття дослідника.

Інтеграцією перерахованих аспектів аналізу виступають парадигмальні призми, які, спираючись на доповнену періодизацію В. Роменця, вибудовують послідовність досліджень свідомості в низці провідних напрямів, а саме:

- методологія рефлексивності (С. Рубінштейн);

- функціоналізм (В. Джеймс);

- глибинна психологія (З. Фрейд, К. Юнг, А. Адлер);

- біхевіоризм (Дж. Уотсон, Б. Скіннер);

- гештальтпсихологія (К. Левін, Е. Йєнш, Ф. Перлз);

- когнітивна психологія (Ж⿱. Брунер, Дж. Гібсон, У. Найссер, Л. Фестінгер);

(C) Kalishchuk Svitlana

DOI (article): https://doi.org/10.32626/2227-6246.2019-46.178-198 
- гуманістична психологія (Дж. Морено, К. Роджерс, К. Ясперс, В. Франкл);

- радянські психологічні школи: київська (М. Боришевський, В. Роменець, О. Ткаченко, П. Чамата); ленінградська (Б. Ананьєв, Л. Веккер); московська (К. АбульхановаСлавська, М. Басов, Л. Виготський, Б. Братусь); тбіліська (Д. Узнадзе); харківська (О. Запорожець, П. Зінченко, О. Леонтьєв);

- нейролінгвістичне програмування (Р. Бендлер, Дж. Гріндлер, Ф. Пьюселік);

- екзистенціальна психологія (Дж. Бьюдженталь, С. Волинський, А. Ленгле, Р. Мей, В. Франкл, І. Ялом);

- трансперсональна психологія (С. Гроф, Дж. Ліллі, Ф. Капра, К. Уїлбер);

- сучасний етап дослідження свідомості та їі новочасний канон (В. Аллахвердов, А. Агафонов, Д. Леонтьєв, О. Лозова, В. Налімов, А. Фурман).

Обрані концептуальні призми пояснення феномену свідомості мають на меті вибудувати координатну площину численних психологічних досліджень свідомості й класифікувати накопичені у психології академічні та практичні погляди на феномен свідомості на певних системотворчих засадах і 3 максимальною науковою обгрунтованістю.

Мета статті - проаналізувати особливості трактування свідомості з позицій трьох психологічних концептуальних засад: рефлексивності, функціоналізму та глибинної психології з дефініцією належності кожного підходу до одного з чотирьох парціальних просторів пояснення свідомості, а саме: «про Світ», «у Світі», «Я і Світ» або «зі Світом»

\section{Завдання статті}

1. Побудувати модель координатної площини психологічних досліджень свідомості особистості.

2. Визначити ознаки психологічного канону зі специфікою взаємодії особистості з об’єктивним атрибутом дійснос-

(C) Kalishchuk Svitlana

DOI (article): https://doi.org/10.32626/2227-6246.2019-46.178-198 
DOI: https://doi.org/10.32626/2227-6246.2019-46

ті - «Світом»у теоріях рефлексивності, функціоналізму та глибинної психології.

\section{Методи та методики дослідження}

Процедура теоретико-методологічного дослідження забезпечує досягнення змістового і структурно-організаційного результатів аналізу феномену свідомості та складається з методу моделювання - визначення засад побудови моделі єдиної площини аналізу численних психологічних теорій свідомості й методу реконструювання - окреслення координатного простору як єдиного методологічного тла опису багатоманітності та різнорідності понять, які використовуються при аналізі феномену свідомості у низці дослідницьких підходів.

\section{Результати та дискусії}

Пошукова площина опису психологічних теорій свідомості окреслюється координатними осями, виокремлення яких здійснено на засаді сполучення чотирьох «іпостасей» психологічного канону за В. Роменцем та І. Манохою (загальне емпіричне, унікальне індивідуальне, всезагальне субстанціальне, вседоскональне відтворення) (Роменець \& Маноха, 1998) і результатів операціоналізації феномену «свідомість» у логіко-предметному, філософському і природничо-науковому його аналізі (Kalishchuk, 2018).

Застосування теорії психологічного канону, на наш погляд, дає змогу створити єдиний простір для численних різновекторних психологічних досліджень феномену «свідомість» i розглянути їх, спираючись на незалежний об'єктивний атрибут - «Світ» і домінуючу функціональну спрямованість свідомості відображати реальний світ і рефлексувати щодо власного відображення.

Ординатою координатної площини досліджень феномену «свідомість» обрана дихотомічна вісь «Загальне емпіричне, зустріч зі світом - Індивідуальне емпіричне, унікальне виокремлення себе зі світу»; абсциса представлена віссю «Ти(C) Kalishchuk Svitlana

DOI (article): https://doi.org/10.32626/2227-6246.2019-46.178-198 
DOI: https://doi.org/10.32626/2227-6246.2019-46

пологічне субстанціальне, всезагальне, атрибутивне - Унікальне субстанціальне, чуттєве захоплення безкінечністю досконалості світу і довіра до нього». Означені координатні осі окреслюють чотири парціальні простори: «свідомість про Світ», «свідомість у Світі», «свідомість Я і Світ» і «свідомість зі Світом» (рис. 1).

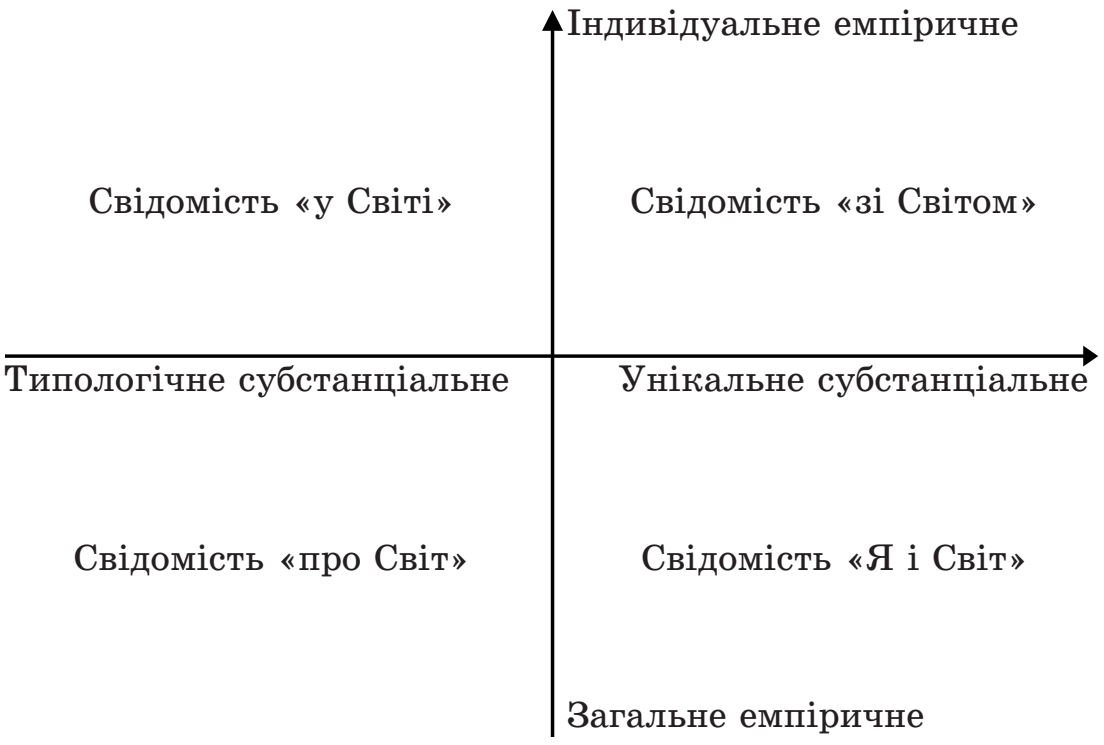

Puc. 1. Головні осі й простори координатної площини досліджень феномену «свідомість»

Можна припустити, що центр координатної площини досліджень феномену «свідомість» представлено методологією рефлексивності, у якій «рефлексія» виступає актом самопізнання людини і знаряддям самопізнання світу з метою досягнення об'єктивності у ставленні людини до себе і до світу.

Місце інших парадигмальних підходів зумовлюється концентрацією уваги дослідників на певних головних атрибутах свідомості, які, на наш погляд, можна визначити 3 метою дефініції генеральної ознаки чи низки непротидій-

(C) Kalishchuk Svitlana

DOI (article): https://doi.org/10.32626/2227-6246.2019-46.178-198 
них ознак, які означуватимуть належність підходу до одного з чотирьох парціальних просторів пояснення свідомості, а саме: «про Світ», «у Світі», «Я і Світ» і «зі Світом».

Психологічний аспект рефлексивності представлено у працях С. Рубінштейна, який філософську постановку питання про відношення свідомості та матерії розвернув у бік відношення «людина i світ» і за проблемою свідомості та буття вбачав ширший запит, а саме: місце людини у світі. С. Рубінштейн наголошує на вихідному значенні положення «людина та буття» для похідного положення «буття і свідомість» (Рубинштейн, 1997). Якостями свідомості, за С. Рубінштейном, виступають: відносини, пізнання і переживання, які визначаються автором як базові категорії ї̈ опису. Проблему свідомості автор убачає в прилученні конкретної людини до безконечного буття, через власну мотиваційну детермінацію. У теорії С. Рубінштейна людина завдяки своїй активності постає об'єктивно існуючою вихідною точкою системи координат світу (Рубинштейн, 1997).

Світ описується С. Рубінштейном як «зріз» людиною «макросвіту» в побудові власного «мікросвіту», а точніше: людський «зріз» як дзеркало Всесвіту (Рубинштейн, 1997). «Зріз» світу здійснюється свідомістю, яка невід'ємна від дії та від причинної включеності людини, від її мотивації. С. Рубінштейном запропоновані ідеї «зрізу», «поверхні» й «екрану», що дають змогу здійснити аналіз дії свідомості. Так, чуттєва даність виступає як «поверхневий» план глибинних шарів реальності на «зрізі» взаємодії людини з існуючим. Чуттєва даність проявляється на «екрані», що реєструє і демонструє результат цієї взаємодії. «Зріз», за С. Рубінштейном, - це акт розкриття і пізнання світу в рамках цього «зрізу», крім того, це спосіб буття людини. «Зріз» опредметнює світ. Такий спосіб самовідображення світу не є дублюванням або копіюванням його - це акт рефлектування в інше, як акт «явлення» іншому, тобто певній людині. Рефлектуючий «зріз» забезпечує створення багатомовності світу. Оскільки дія рефлексив(c) Kalishchuk Svitlana

DOI (article): https://doi.org/10.32626/2227-6246.2019-46.178-198 
ності безконечна, то і дія створення багатопредставленості та багатомовності світу теж безконечна. Індивідуальність і «неповторність ансамблю" взаємодії людини зі світом на засаді «рефлектування в інше» задає потенційну можливість вироблення безлічі «зрізів» реальності та необхідність установлення між ними певної координації. Цей процес потенційно здатний активувати всі можливі аспекти дії свідомості: «свідомість про Світ», «свідомість у Світі», «свідомість Я і Світ» і «свідомість зі Світом» (Рубинштейн, 1997).

Простору «свідомість у Світі», що створюється осями «Типологічне субстанціальне - Індивідуальне емпіричне», в силу своєї феноменологічності відповідають погляди на процесуальність свідомості В. Джеймса, згідно з якими свідомість первісно функціонально цілісна і являє собою «потік» . «Потік», за В. Джеймсом, включає в себе нероздільність свідомості й світу, розуму й тіла. Свідомість виступає одночасно і миттєвим, і неперервним процесом, у якому імпульси існують усередині хвилі й хвилі існують усередині імпульсів (Джеймс, 1991).

В. Джеймс виокремив такі характеристики свідомості:

- кожен стан свідомості прагне бути частиною особистої свідомості, але проявляє тільки певну частину цілого. Тому виникає ідея «абсолютної роз’єднаності» свідомості та її замкненості на собі;

- кожен стан свідомості унікальний i неповторний, тому свідомість має динамічний характер, свідомість носить якість постійної мінливості;

- процес свідомості безперервний, тому спроби виокремити елементи свідомості безрезультатні;

- головна особливість свідомості - це незупинна здібність здійснювати відбір, тобто вибірковість, селективність якої задана інтересами і фокусуванням уваги;

- свідомість - це потік суб'єктивних думок;

- свідомість має більш-менш визначену частину - ядро та «бахрому» (периферію) - павутину з асоціацій і почуттів; (C) Kalishchuk Svitlana DOI (article): https://doi.org/10.32626/2227-6246.2019-46.178-198 
DOI: https://doi.org/10.32626/2227-6246.2019-46 2019. Випуск 46

- свідомість одночасно i неперервна, i дискретна (Джеймс, 1991).

У подальших обговореннях В. Джеймс описує свідомість як «пульсацію», коли в одній характеристиці завжди знаходиться інша» (James, 1971). А тому в первинному плині свідомості, згідно з В. Джеймсом, перебуває співіснування «сутнісного» $\mathrm{i}$ «плинного» аспектів, а «роль свідомості полягає у співвідношенні ... одночасних можливостей ... шляхом придушення або нарощення сили уваги» (Хант, 2004: 193). Свідомість, на думку В. Джеймса, являє собою і реально існуюче, i перехідне, і пульсацію, і безперервну хвилю. Автор наголошує, що свідомість не містить ніяких матеріальних одиниць та елементів. Образи й почуття являють собою затримки усвідомлення і відображають уповільнені частини «потоку». Швидкісні ж частини надають спрямованість свідомості. Перехідні моменти - це «ореоли», які відкривають «смисли, що відчуваються», котрі породжують думки. На питання про існування свідомості В. Джеймс відповідав негативно, не визнаючи наявності унікальних, зумовлюючих ïï характеристик і самостійної сутності. В. Джеймс наголошує, що не існує нетілесної свідомості, незалежної від індивідуального досвіду, що включає в себе простір і час. Автор мав на увазі відсутність характеристик свідомості, які б протиставили свідомість і Світ. За В. Джеймсом, свідомість і Світ - це різні організації однієї фундаментальної основи, які не протилежні, як «фарба на палітрі, або фарба на полотні» (Хант, 2004). Сутність буття, за В. Джеймсом, це точка перетину суб'єктивного (де саме ми присутні) й об'єктивного (зовнішні чинники). Отже, «потік» В. Джеймса являє собою дзеркало фізичної реальності, яка стикається зі світом життя і є нероздільною з ним. Це положення базується на позиції радикального емпіризму і виступає центральною ланкою історичних і концептуальних стадій розвитку поглядів В. Джеймса на свідомість і відносить його погляди до квадранту «свідомість у Світі».

(C) Kalishchuk Svitlana

DOI (article): https://doi.org/10.32626/2227-6246.2019-46.178-198 
Свідомість у глибинній психології не визначається, а пояснюється через несвідоме, яке змістовно наповнено процесами, що опосередковано проявляються у свідомості. Саме тенденція пояснювати те, що носить характер суб'єктивно явного через конструкт, який по суті є суб'єктивно невідомим, відносить цей напрям дослідження до площини «про Світ», у квадрант, який окреслено осями: «Загальне емпіричне - Типологічно субстанціональне». Психоаналіз 3. Фрейда, аналітична психологія К. Юнга й індивідуальна психологія А. Адлера інтерпретують суб'єктивний досвід особистості різними категоріями, розкриваючи різні його грані, але все ж загальна призма залишається єдиною: "свідомість не завжди знає, що вона знає про себе, і зовсім нічого не знає про те, чого не знає, а саме: про несвідоме» (Аллахвердов, 2001: 179). Водночас у глибинній психології свідомість «Я» та несвідоме «Воно» парадоксально переплетені. 3 одного боку, свідомість є породженням несвідомого, його продуктом, з іншого боку, несвідоме - це те, що було витиснуте зі свідомості. При побудові ієрархічної інтерпретації, в першому випадку, свідомість є нащадком несвідомого, а в другому випадку, свідомість - це прародич несвідомого (Лоренцер, 1996).

3. Фрейд обгрунтовує самостійну структуру несвідомого («Воно»), яке керує свідомістю («Я»), але не має жодної 3 ознак свідомого (Фрейд, 1990). Тому людина, на думку автора, завжди пояснює свою поведінку, але не завжди те, що свідомістю вбачається як дійсне пояснення власних вчинків як наслідок певної суб'єктивно проінтерпретованої причини, відповідає реальним, незалежним від самої людини обставинам. Крім того, 3. Фрейд доводить ненадійність і невірогідність свідомих переживань людини, обгрунтовуючи це тим фактом, що сама свідомість невірогідна (Фрейд, 1990). Із цього положення автором зроблено висновок про те, що зміст свідомості ошукує нас, але він робить це не випадково. Існує блок переробки інформації, який 3. Фрейд називає «цензурою», що контролює i приймає рішення, яку інфор-

(C) Kalishchuk Svitlana

DOI (article): https://doi.org/10.32626/2227-6246.2019-46.178-198 
мацію доводити до свідомості. Опрацювання дії «цензури» та пошук методичних можливостей емпіричного вивчення істинного змісту свідомості призвели до визначення необхідності аналізу «маленьких випадковостей», а саме: випадкові помилки, описки, пробіли у поясненні власної поведінки, забування імен, речей або власних намірів. Наголошуючи на наявності всезагального світового зв'язку, 3. Фрейд указує, що не існує малозначущих подій. Разом із тим, «цензуру» цікавлять лише ті події, що пов'язані з неприємними або небажаними переживаннями. Крім того, пояснення фільтруючої дії «цензури» призвели до відкриття існування механізмів відбору інформації, а саме психологічних захистів: витиснення, регресії, проекції, сублімації, які вберігають свідомість від «небажаної» інформації.

Згідно з поглядами К. Юнга, свідомість теоретично не має меж, а тому існує даність динамічного переродження особистості й свідомості у процесі індивідуалізації або особистісної інтеграції в напрямку збільшення їі цілісності. Поняття «розвиток» та «індивідуалізація» протилежні. Розвиток, за К. Юнгом, включає інтегрування у свідомість нового матеріалу, зокрема придбання знань про світ і про себе, й тому виконує функцію зростання поінформованості свідомості. Індивідуалізація є прагненням до єдності свідомого і несвідомого, це процес створення цілісності через установлення зв'язків між «Его» та «Самістю» (Фрейджер \& Фэйдимен, 2002).

Кожна з головних рис особистості, а саме: «Его», «Персона», «Тінь», «Аніма» («Анімус»), «Самість», являють собою, за К. Юнгом, архетипи як наслідувані схильності відповідати світу певним засобом і первісні образи й спомини про інстинктивні енергії колективного несвідомого. «Его» являє собою центр свідомості, а «Самість»- це центр усієї психіки, яка складається зі свідомих і несвідомих процесів. «Его» забезпечує почуття сталості у житті, протидіє порушенню зафіксованого гомеостазу, спрямовує людину планувати й аналізувати свій досвід. На початку процесу індивідуалізації (C) Kalishchuk Svitlana

DOI (article): https://doi.org/10.32626/2227-6246.2019-46.178-198 
DOI: https://doi.org/10.32626/2227-6246.2019-46 2019. Випуск 46

здійснюється розкриття «Персони», яка теж відноситься до свідомого аспекту особистості, виконує важливу функцію захисту, але по суті не має можливості інтегрувати «Самість", оскільки приховує їі. «Персона» носить інструментальний і захисний характер і не являє собою постійну частину особистості.

Той матеріал, що стоїть за певним архетипом, у кожному унікальному випадку здатний викликати найпотужніші емоції, які, згідно з К. Юнгом, виступають важливою силою запускання процесу індивідуалізації. «Емоція є головним джерелом свідомості» (Jung, 1954: 96). Тобто, автор підкреслює, що кожна реальна внутрішня зміна має емоційну компоненту. Крім того, функція інтуїції вагомо вливає на зміст свідомості.

Сам процес зростання свідомості автор описуе як:

1) зменшення пласту особистого несвідомого, що накладався на колективне несвідоме;

2) розривання попередньої зафіксованості свідомості у надчуттєвий особистий світ інтересів;

3) зменшення вразливості свідомості;

4) скорочення набору егоїстичних бажань, страхів, надій і амбіцій;

5) прийняття функції зв’язку зі світом об'єктів, що забезпечує нерозривну єдність зі світом загалом.

Свідомість керує волею, яку К. Юнг розглядає як енергію. Розвиток волі пов'язаний із засвоєнням культурних цінностей і моральних стандартів. Воля залежить від свідомого мислення та дії, має опосередковану владу над інстинктивними процесами, але сама, своєю чергою, не може активно впливати на несвідомі процеси.

К. Юнг виокремлює чотири фундаментальні психологічні функції: мислення, почуття, відчуття й інтуїцію, кожна 3 яких здатна розвинутися за екстравертним або інтровертним типом (Jung, 1954). Означені функції й типи забезпечують виокремлення шістнадцяти функціональних різновидів особ-

(C) Kalishchuk Svitlana

DOI (article): https://doi.org/10.32626/2227-6246.2019-46.178-198 
DOI: https://doi.org/10.32626/2227-6246.2019-46

ливостей і специфіки свідомості особистості. Присутність провідної та підлеглої функцій дає змогу особистості вибудувати чітко окреслений підхід до світу, в силу того, що його сприймання є результатом комбінації всіх функцій.

Метою процесу індивідуалізації виступає процес переміщення «Самістю» «Его» у центр психіки на однакову відстань від свідомості та несвідомого. У результаті такого переміщення отримується знання і привноситься єдність в інтеграцію свідомого і несвідомого матеріалу, крім того, «Самість» позбавляється масок «Персони» та власної сили влади і впливу з опорою на колективне й особисте несвідоме (Фрейджер \& Фэйдимен, 2002).

В індивідуальній психології А. Адлера підкреслюється, що в перші п'ять років життя у людини формується єдність свідомості та вибудовуються відносини між свідомістю і тілом (Adler, 1931: 34). Вектор розвитку має напрям від спадкоємного матеріалу і вражень від оточуючого світу до пристосування їх до свого прагнення переважати. Первісна дитяча «кристалізація» особистості проявляється у:

1) значенні, яке надається власному життю;

2) меті, яку намагається досягнути;

3) способі досягнення мети;

4) емоційних схильностях.

Попереднє та нове розвивальне розуміння життя, за А. Адлером, як нова кристалізація підкоряється загальній тенденції, що можна відобразити схематично (рис. 2).

Комплекс невідповідності

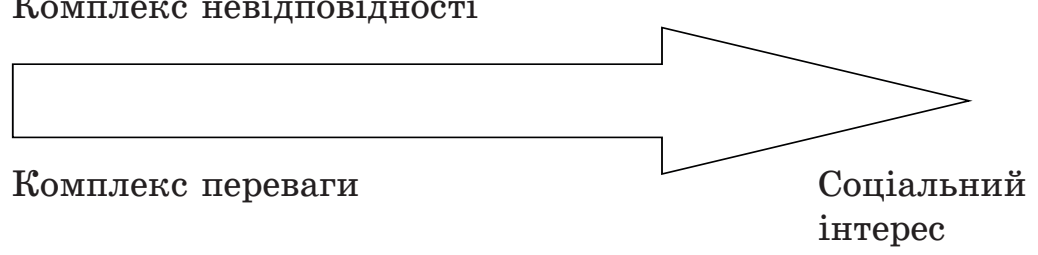

Puc. 2. Вектор і сили «кристалізації» особистості за А. Адлером

(C) Kalishchuk Svitlana

DOI (article): https://doi.org/10.32626/2227-6246.2019-46.178-198 
Новий самовираз особистості залежить від її життєвого стилю, який є унікальним способом взаємодії з життям i пристосуванням до нього задля досягнення власних цілей.

Г. Мозак визначив основні складові життєвого стилю (Mosak, 1989):

1) «Я-концепція» як уявлення про себе;

2) ідеал себе - це міркування про себе такого, яким повинен бути;

3) образ світу як уявлення про світ, людей, природу та вимоги світу до індивіда;

4) етичні переконання особистості.

Означені складові акумулюють індивідуальну концепцію світу і себе, яка має якість посилювати сама себе. Таку індивідуальну концепцію А. Адлер назвав «схема апперцепції». Схема апперцепції належить до перцепції (сприйняття) і включає в себе суб'єктивну інтерпретацію отриманих стимулів: «Ви знаходите те, що планували знайти» (Adler, 1964: 100). Тому особиста концепція світу зумовлює поведінку індивіда.

Схема апперцепції за своєю суттю виступає смисловою моделлю репрезентації свідомістю світу і себе в ньому. А. Адлер підкреслював, що на різноманітні впливи людина реагує активно і творчо, шукаючи одні враження і відхиляючи інші. Індивід вибірково систематизує й усвідомлює досвід, реалізовуючи індивідуальну схему апперцепції та формуючи виразну модель ставлення до світу.

На питання, що виступає джерелом творчої енергії життя, яка призводить до бажання розвитку і досягнень, А. Адлер відповідає: це телеологічна сила, у якій тілесні й психологічні зусилля діють разом. Отже, за А. Адлером, конкретна ціль досягається за допомогою творчої енергії, яка ідентична «Я».

Свідомі процеси в індивідуальній психології А. Адлера ціленаправлені тією ж мірою, що і несвідомі, та слугують цілям індивіда. Зрозуміти людину можна через оцінку їі C Kalishchuk Svitlana DOI (article): https://doi.org/10.32626/2227-6246.2019-46.178-198 
життєвого стилю, який виступає лінзою бачення себе i свого життя. Метод «Найранішого спомину», запропонований автором, виступає ефективною експрес-технікою розкриття життєвого стилю людини.

А. Адлер підкреслює, що поведінка зумовлюється спадковістю й оточенням. Головна сила досягнення цілей - це прагнення до щастя й успіху. Смисл життя визначається тим, як індивід до нього ставиться і чи актуальними є соціальний інтерес і кооперація. Психологічне зростання проявляється у русі від егоцентричної цілі особистої переваги до позиції конструктивного впливу на оточуюче середовище і розвиток суспільства. Три головні завдання життя: праця, дружба та любов - це різні грані можливості жити конструктивно в оточуючому світі.

Категорії «тіло», «соціальні відносини», «воля», «емоції», «інтелект», «Я» розкриваються А. Адлером із позиції еволюційного процесу усвідомленого пристосування до оточуючого світу, який означає прагнення до досконалості та найефективнішого керування оточуючим середовищем. Згідно з А. Адлером, «Я»- це динамічний принцип, а не структура. Тому «Я» проявляється винятково у взаємодії з оточуючим світом, без якого «Я» не існує.

Отже, А. Адлер визначив полем несвідомого одну з головних сил розвитку індивіда, а саме: прагнення до влади та переваги, і зробив значний акцент на обгрунтуванні ролі соціального інтересу, співпраці, життєвого стилю і схеми апперцепції індивіда, що зумовлюють його досвід і впливають на свідому будову конструктивного образу оточуючого людину світу i, безперечно, належать до свідомості.

\section{Висновки}

Окреслений осями «Загальне емпіричне, зустріч зі світом - Індивідуальне емпіричне, унікальне виокремлення себе зі світу» та «Типологічне субстанціальне, всезагальне, атрибутивне - Унікальне субстанціальне, чуттєве захоплен(c) Kalishchuk Svitlana

DOI (article): https://doi.org/10.32626/2227-6246.2019-46.178-198 
DOI: https://doi.org/10.32626/2227-6246.2019-46 2019. Випуск 46

ня безкінечністю досконалості світу і довіра до нього» координатний простір може виступати єдиним методологічним тлом опису різноманітності та різнорідності понять, які використовуються для трактування феномену свідомості, а також дає змогу подолати:

1) суб'єктивність переконання й усвідомлення певного дослідника з його картиною світу та розумінням закономірностей об'єктивного зв'язку елементів, що складають таку картину;

2) складність досліджуваного явища, яке мало диференціюється на більш елементарні;

3) глобальність категорії «свідомість», що охоплює практично всі рівні психічного відображення, починаючи 3 відчуття і закінчуючи цілісною дією самосвідомості та саморефлексії;

4) різнобічність внутрішнього змісту категорії «свідомість» .

Означені координатні осі окреслюють чотири парціальні простори: «свідомість про Світ», «свідомість у Світі», «свідомість Я і Світ» і «свідомість зі Світом», які можна розглядати як тло пошуку суттєвих властивостей та ознак свідомості,

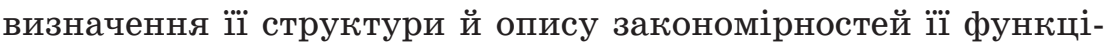
онування. Центр координатної площини досліджень феномену «свідомість» представлено методологією рефлексивності. Квадранту «свідомість у Світі», з найближчим розташуванням до осі ординат «Індивідуальне емпіричне», відповідають погляди на процесуальність свідомості В. Джеймса. До площини «про Світ» можна віднести теорії дослідження свідомості у глибинній психології в силу пояснення головних його рушійних сил через несвідоме.

\section{Література}

Аллахвердов В. М. Поддается ли сознание разгадке? Психология сознания. Санкт-Петербург : Питер, 2001. С. 100-101.

Джемс У. Психология. Москва : Педагогика, 1991. С. 56-80.

(c) Kalishchuk Svitlana

DOI (article): https://doi.org/10.32626/2227-6246.2019-46.178-198 
DOI: https://doi.org/10.32626/2227-6246.2019-46 2019. Випуск 46

Каліщук С. М. Об’єктивний підхід до трактування свідомості: нейрофізіологічний, фізичний та математичний дискурси. Проблели сучасної психологї: зб. наук. праць Кал'янець-Подільського національного університету ілені Івана Огієнка, Інституту психології імені Г. С. Костюка НАПН Украӥни. Кам'янець-Подільський : Аксіома, 2019. Вип. 45. С. 178-202.

Леонтьев А. Н. Деятельность. Сознание. Личность. Москва : Политиздат, 1975. 130 с.

Лоренцер А. Археология психоанализа. Москва : Наука, 1996. С. 215.

Налимов В. В. Спонтанность сознания: Вероятностная теория смыслов и смысловая архитектоника личности. Москва : Прометей, 1989. $182 \mathrm{c}$.

Прист С. Теории сознания. Москва : Идея-Пресс, 2000. 288 с.

Рубинштейн С. Л. Человек и мир. Москва : Наука, 1997. С. 138-160.

Фрейд 3. Психология бессознательного. Москва : Наука, 1990. 354 с.

Фрейджер Р., Фейдимен Дж. Личность. Теории, упражнения, эксперименты. Москва : Наука, 2002. 403 с.

Фурман А. В. Свідомість як передумова психологічного пізнання і професійного методологування. Наука і освіта. 2017. № 3. С. 5-10.

Хант Г. О природе сознания. С когнитивной, феноменологической и трансперсональной точек зрения. Москва : АCT, 2004. 555 с.

Adler, A. (1931). What life should mean to you. Boston : Little, Brown. $154 \mathrm{p}$.

Adler, A. (1964). Superiority and social interest: A collection of later writings. New York : Viking Press. 205 p.

James, W. (1971). Essays in radical empiricism and a pluralistic universe. New York : E. P. Dutton. 360 p.

Jung, C. (1954). Psychological aspects of the mother archetype. In Collected works, 9, 1, 105. Originally published.

Kalishchuk, S. (2018). Construction of ontological models of consciousness of personality. PNAP Scientific Journal of Polonia, 1 (26), 95-100. Czestochowa.

Mosak, H. (1989). Adlerian psychotherapy. Itasca, IL : F. E. Peacock. 203 p.

\section{References}

Allakhverdov, V.M. (2001). Poddayotsia li soznanie razgadke? [Is consciousness a solution?]. Psikhologiia soznaniia [Psychology of consciousness]. Saint Petersburg: Piter [in Russian].

James, U. (1991). Psikhologiia [Psychology]. Moskva: Pedagogika [in Russian].

(C) Kalishchuk Svitlana

DOI (article): https://doi.org/10.32626/2227-6246.2019-46.178-198 
Kalishchuk, S.M. (2019). Obiektyvnyi pidkhid do traktuvannia svidomosti: neirofiziolohichnyi, fizychnyi ta matematychnyi diskursy [Objective approach to the consciousness treatment: neurophysiological, physical and mathematical discourses]. Problemy suchasnoi psykholohii - Problems of modern psychology: Collection of research papers of Kamianets-Podilskyi National Ivan Ohiienko University, G.S. Kostuk Institute of Psychology of the National Academy of Educational Sciences of Ukraine, 45, 178-202. Kamianets-Podilskyi: Aksioma [in Ukrainian].

Leontiev, A.N. (1975). Deiatelnost. Soznaniie. Lichnost [Activity. Consciousness. Personality]. Moskva: Politizdat [in Russian].

Lorentser, A. (1996). Arkheologiia psikhoanaliza [Archeology of psychoanalysis ]. Moskva: Nauka [in Russian].

Nalimov, V.V. (1989). Spontannost soznaniia: Veroiatnostnaia teoriia smyslov $i$ smyslovaia arhitektonika lichnosti [Spontaneity of consciousness: Probabilistic theory of meanings and semantic architectonics of personality]. Moskva: Prometei [in Russian].

Prist, S. (2000). Teorii soznaniia [Theories of consciousness]. Moskva : Ideia-Press [in Russian].

Rubinshtein, S.L. (1997). Chelovek $i$ mir [Man and the world]. Moskva : Nauka [in Russian].

Freyd, Z. (1990). Psikhologiia bessoznatelnogo [Psychology of the unconscious]. Moskva: Nauka [in Russian].

Freidzher, H., Feidimen, Dzh. (2002). Lichnost. Teorii, uprazhneniia, eksperimenty [Theories, exercises, experiments]. Moskva: Nauka [in Russian].

Furman, A.V. (2017). Svidomist yak peredumova psykholohichnoho piznannia i profesiinoho metodolohuvannia [Consciousness as a prerequisite for psychological knowledge and professional methodology]. Nauka i osvita-Science and Education, 3, 5-10 [in Ukrainian]. Khant, G. (2004). O prirode soznaniia. S kognitivnoi, fenomenologicheskoi $i$ transpersonalnoi tochek zreniia [On the nature of consciousness. From cognitive, phenomenological and transpersonal points of view]. Moskva: AST [in Russian].

Adler, A. (1931). What life should mean to you. Boston: Little, Brown.

Adler, A. (1964). Superiority and social interest: A collection of later writings. New York: Viking Press.

James, W. (1971). Essays in radical empiricism and a pluralistic universe. New York: E.P. Dutton.

Jung, C. (1954). Psychological aspects of the mother archetype. In Collected works (Vol. 9, Part 1). Originally published.

(C) Kalishchuk Svitlana

DOI (article): https://doi.org/10.32626/2227-6246.2019-46.178-198 
DOI: https://doi.org/10.32626/2227-6246.2019-46 2019. Випуск 46

Kalishchuk, S. (2018). Construction of ontological models of consciousness of personality. PNAP Sientific Journal of Polonia. Czestochowa.

Mosak, H. (1989). Adlerian psychotherapy. Itasca: IL: F. E. Peacock.

Калішук Світлана. Зв'язок "Свідомості» й "Світу» в концептуальних теоріях рефлексивності, функціоналізму і глибинної психології

\section{АНОТАЦІЯ}

Автором задано дослідницькі аспекти опису концептуального психологічного рівня пояснення свідомості особистості: історико-психологічний, процесуально-динамічний і персоналістичний. Вибудовано низку парадигмальних призм дослідження свідомості у послідовності від методології рефлексивності до сучасного етапу та ії новочасного канону. Запропоновано методологічну модель єдиної площини аналізу численних психологічних теорій свідомості. Виокремлено координатні осі дослідницької площини теорій свідомості. Ординатою обрано дихотомічну вісь «загальне емпіричне, зустріч зі світом - Індивідуальне емпіричне, унікальне виокремлення себе зі світу»; абсцису представлено віссю "Типологічне субстанціальне, всезагальне, атрибутивне - Унікальне субстанціальне, чуттєве захоплення безкінечністю досконалості світу і довіра до нього». Проаналізовано особливості трактування свідомості з позицій трьох психологічних концептуальних засад: рефлексивності, функціоналізму та глибинної психології з дефініцією належності підходу до одного з чотирьох парціальних просторів пояснення свідомості, а саме: «про Світ», "у Світі», "Я і Світ» або "зі Світом». Визначено, що індивідуальність $і$ «неповторність ансамблю» взаємодії людини зі світом на засаді "рефлектування в інше» задає потенційну можливість вироблення безлічі "зрізів» реальності. Тому методологію рефлексивності розміщено у центр координатної площини досліджень свідомості в силу того, що цей процес потенційно здатний активувати всі можливі аспекти дії свідомості: "свідомість про Світ», "свідомість у Світі», "свідомість Я і Світ» i «свідомість зі Світом». Квадранту "свідомість у Світі», що створюється осями "Типологічне субстанціальне - Індивідуальне емпіричне», в силу своєї феноменологічності відповідають погляди на процесуальність свідомості В. Джеймса, згідно з якими свідомість первісно функціонально цілісна і являє собою "потік». Тенденція пояснювати те, що носить характер суб'єктивно явного через конструкт, який по суті є суб'єктивно (C) Kalishchuk Svitlana

DOI (article): https://doi.org/10.32626/2227-6246.2019-46.178-198 http://journals.uran.ua/index.php/2227-6246 
DOI: https://doi.org/10.32626/2227-6246.2019-46 2019. Випуск 46

невідомим, відносить глибинний напрям дослідження до площини «про Світ», у квадрант, який окреслено осями “Загальне емпіричне - Типологічно субстанціональне».

Ключові слова: "свідомість про Світ», "свідомість у Світі», "свідомість Я і Світ», "свідомість зі Світом», методологія рефрлексивності, функціоналізм, глибинна психологія.

Калищук Светлана. Связь "Сознания» и "Мира» в концептуальных теориях рефлексивности, функционализма и глубинной психологии

\section{АННОТАЦИЯ}

Автором заданы исследовательские аспекты описания концептуального психологического уровня объяснения сознания личности: историко-психологический, процессуально-динамический и персоналистический. Построена последовательность парадигмальных призм исследования сознания от методологии реслексивности до современного этапа и его нового канона. Предложена методологическая модель единой плоскости анализа многочисленных психологических теорий сознания. Выделены координатные оси исследовательской плоскости теорий сознания. Ордината представлена дихотомической осью "Общее эмпирическое, встреча с миром - Индивидуальное эмпирическое, уникальное отделение себя из мира»; абсцисса представлена осью "Типичное субстанциональное, всеобщее, атрибутивное - Уникальное субстанциональное, чувственный восторг от бесконечного совершенства мира и доверие к нему». Проанализированы особенности интерпретации сознания с позиции трех психологических оснований: рефлексивности, функционализма и глубинной психологии с вычленением принадлежности каждого подхода к одному из четырех парциальных пространств объяснения сознания: "о Мире», "в Мире», "Я и Мир», "с Миром». Определено, что индивидуальность и неповторимость ансамбля взаимодействия человека с миром на основе "рефлексирования в другое» задает потенциальную возможность выработки бесконечности "срезов» реальности. Поэтому методология рефрлексивности помещена в центр координатной плоскости исследования сознания в силу того, что этот процесс потенциально способен активировать все возможные аспекты действия сознания: «сознание о Мире», "сознание в Мире», "сознание Я и Мир», "сознание с Миром». Квадранту «сознание в Мире», который создается осями «Типичное суб-

(C) Kalishchuk Svitlana

DOI (article): https://doi.org/10.32626/2227-6246.2019-46.178-198 
DOI: https://doi.org/10.32626/2227-6246.2019-46 2019. Випуск 46

станциональное - Индивидуальное субстанциональное», в силу своей феноменологичности соответствуют взгляды на процессуальность сознания У. Джеймса, согласно которым сознание первично функционально целостно и представляет собой «поток». Тенденция объяснять то, что носит характер субъективно явного через конструкт, который по сути является субъективно неизвестным, относит глубинное направление исследований сознания к плоскости «о Мире», в квадрант, который очерчено осями "Общее эмпирическое - Типическое эмпирическое».

Ключевые слова: "сознание о Мире», "сознание в Мире», "сознание Я и Мир», "сознание с Миром», методология рефлексивности, функционализм, глубинная психология.

Original manuscript received September 19, 2019 Revised manuscript accepted October 20, 2019 